\title{
New host records of Brazilian pentastomid species
}

\author{
Brito, SV. ${ }^{*}$, Almeida, WO. ${ }^{b}$, Anjos, LA. ${ }^{c}$ and Silva, RJ. ${ }^{c}$ \\ aPrograma de Pós-Graduação em Ciências Biológicas (Zoologia), Departamento de Sistemática e Ecologia - DSE, \\ Centro de Ciências Exatas e da Natureza - CCEN, Universidade Federal da Paraíba - UFPB, \\ Cidade Universitária, Campus I, CEP 58059-900, João Pessoa, PB, Brazil \\ bDepartamento de Química Biológica, Centro de Ciências Biológicas e da Saúde - CCBS, \\ Universidade Regional do Cariri - URCA, Campus do Pimenta, CEP 63105-100, Crato, Ceará, Brazil \\ ${ }^{\mathrm{c}}$ Departamento de Parasitologia, Instituto de Biociências, Universidade Estadual Paulista -UNESP, \\ Distrito de Rubião Junior, s/n, CEP 18618-970, Botucatu, SP, Brazil \\ *e-mail: samuelvieirab@yahoo.com.br
}

Received April 26, 2011 - Accepted June 22, 2011 - Distributed May 31, 2012

\begin{abstract}
Pentastomida is a taxon of parasitic organisms infecting generally the respiratory system of vertebrates, mainly reptiles. Although this taxon is very important for understanding the phylogeny of the Metazoa, it has received little attention. In Brazil, there are few collections that include species of pentastomids, that is, only the Helminthological Collection of the Oswaldo Cruz Institute (CHIOC), the Invertebrate Collection of the Zoology Laboratory of the Regional University of Cariri (LAZ-URCA) and the Helminthological Collection of the Botucatu Institute of Biosciences (CHIBB). The present study describes the species of pentastomids deposited in CHIBB. When found, the pentastomids were mounted on slides in Hoyer's medium and identified. Four species of pentastomids were recognised and three others were identified at the genus level, while four new hosts for the species of pentastomids were recorded.
\end{abstract}

Keywords: pentastomids, parasitism, tongue worms, Squamata fauna.

\section{Novos registros de hospedeiros para espécies de pentastomídeos do Brasil}

\begin{abstract}
Resumo
Pentastomida é um táxon de organismos parasitas obrigatórios de sistema respiratório de vertebrados, principalmente répteis. Embora esse táxon seja muito importante para a compreensão da filogenia dos Metazoa, tem recebido pouca atenção. No Brasil, existem poucas coleções que abrigam espécies de pentastomídeos, quais sejam: a Coleção Helmintológica do Instituto Oswaldo Cruz (CHIOC), a Coleção de Invertebrados do Laboratório de Zoologia da Universidade Regional do Cariri (LAZ-URCA) e a Coleção Helmintológica do Laboratório de Parasitologia de Animais Silvestres (LAPAS). O presente trabalho descreve as espécies de pentastomídeos depositados na Coleção Helmintológia do LAPAS. O trato respiratório e as cavidades do corpo dos répteis foram removidos e analisados sob Microscópio Esteroscópico; quando encontrados os pentastomídeos, foram montados slides em meio Hoyer e identificados. Foram identificadas quatro espécies e outras três ficaram identificadas no nível de gênero, tendo sido registrados quatro novos hospedeiros para as espécies de pentastomídeos.
\end{abstract}

Palavras-chave: pentastomida, Parasitismo, vermes língua. 


\section{Introduction}

The taxon Pentastomida comprises approximately 131 species distributed in seven families, namely Cephalobaenidae, Linguatulidae, Porocephalidae, Rallietiellidae, Reighardiidae, Sebekidae and Subtriquetridae (Almeida \& Christoffersen, 1999), where they are preferentially pulmonary parasites of vertebrates, mainly reptiles (Almeida \& Christoffersen, 2002).

Data regarding the ecology of pentastomids are important, but they are scarce, and in most cases these data were obtained from studies of zoological, animal house and snake house collections. In Brazil, the first works on these parasites were recorded in hosts from the Helminthological Collection of the Oswaldo Cruz Institute (CHIOC), which is the principal reference collection in terms of the diversity of neotropical pentastomids (Motta, 1963a,b; Rego, 1981; 1983; 1984). Another collection, smaller and under construction in recent years, comprises the Zoology Laboratory of the Regional University of Cariri (LZ URCA) with a total of 67 specimens of the following species Cephalobaena tetrapoda (Heymons, 1922) (LZ URCA 43-44, 158-163), Raillietiella furcocerca (Diesing, 1835) (LZ URCA 164-170), Raillietiella gigliolii (Hett, 1924) (LZ URCA 99-101; 320-330), Raillietiella mottae (Almeida, Freire and Lopes, 2008) (LZ URCA 201-212; 351-353; 401-402), Raillietiella sp. (LZ URCA 157)

Porocephalus stilesi (Sambon, 1910) (LZ URCA 331345) Porocephalus sp. (LZ URCA 346-350). The majority of the specimens of this collection are from the Caatinga biome (Almeida et al., 2006a, b; Almeida et al., 2008a, b; Almeida et al., 2009a, b; Anjos et al., 2007; Anjos et al., 2008; Lopes et al., 2006).

The aim of the present work was to enrich our knowledge of the biology of pentastomids by analysing the specimens and their hosts deposited in the Helminthological Collection of the Botucatu Biosciences Institute (CHIBB), located in the Laboratory of the Parasitology of Wild Animals (LAPAS) of the Universidade Estadual de São Paulo (UNESP).

\section{Material and Methods}

The respiratory tracts and body cavities of the reptiles were removed and the presence of pentastomids determined by examination under a stereomicroscope. All pentastomids found were cleared in Hoyer's medium and subsequently mounted on slides. Identifications were based on the dimensions of the hooks and copulatory spicules of the males that were measured using a microscope equipped with an ocular micrometer.

\section{Results}

Four species of pentastomids were found, namely Sebekia oxycephala (Sambon, 1922), Porocephalus sp., Raillietiella freitasi (Mota \& Gomes, 1968) and Raillietiella furcocerca (Table 1), plus the morphospecies Raillietiella sp.1 and Raillietiella sp.2.

Table 1. Records of pentastomids deposited in the Helminthological Collection of the Botucatu Biosciences Institute (CHIBB).

\begin{tabular}{|c|c|c|c|c|}
\hline Host & Parasite & Infection site & Locality & CHIBB* \\
\hline \multicolumn{5}{|l|}{ Crocodylia } \\
\hline Caiman yacare & Sebekia oxycephala & Lung & Corumbá, MS & 2394 \\
\hline C. yacare & S. oxycephala & Stomach & Corumbá, MS & 2395 \\
\hline C. yacare & S. oxycephala & Intestine & Corumbá, MS & 2396 \\
\hline \multicolumn{5}{|l|}{ Squamata - snakes } \\
\hline \multicolumn{5}{|l|}{ Boidae } \\
\hline Boa constrictor amarali & Porocephalus sp. & Coelomic cavity & unknown & 1108 \\
\hline \multicolumn{5}{|l|}{ Dipsadidae } \\
\hline Liophis poecilogyrus & Raillietiella sp.2 & Lung & Corumbá, MS & 2099 \\
\hline \multicolumn{5}{|l|}{ Viperidae } \\
\hline Bothropoides mattogrossensis & Raillietiella sp.1 & Lung & Corumbá, MS & 2116 \\
\hline Crotalus durissus & Porocephalus sp. & Lung & Corumbá, MS & $1116,1142,1172$ \\
\hline C. durissus & Raillietiella furcocerca & Stomach & Pirambóia, SP & 1932 \\
\hline \multicolumn{5}{|l|}{ Squamata - lizards } \\
\hline \multicolumn{5}{|l|}{ Scincidae } \\
\hline Trachylepis atlantica & Raillietiella freitasi & Lung & $\begin{array}{l}\text { Fernando de } \\
\text { Noronha, PE }\end{array}$ & 2928 \\
\hline
\end{tabular}

*Numbers in the last column are the accession numbers of voucher species in CHIBB - Helminthological Collection of the Department of Parasitology, Institute of Biosciences, Universidade Estadual Paulista. 


\section{Discussion}

We report here the first record of infection by pentastomids in the snake species Bothropoides mattogrossensis (Amaral, 1925), Thamnodynastes chaquensis (Bergna \& Alvarez, 1993) and Liophis poecilogyrus (Wied, 1825) and the crocodilian Cayman yacare (Daudin, 1802).

Sebekia oxycephala has already been reported as a parasite of the following vertebrates: fish species Pseudoplatystoma fasciatum (Linnaeus, 1766), Pygocentrus piraya (Müller \& Troschel, 1848), Synbranchus marmoratus (Bloch, 1795), Stenarchus albifrons (Bloch \& Schneider, 1801), Potamotrygon motoro (Müller \& Henle, 1841), Electrophorus electricus (Linnaeus, 1766), Salmo tamuco (Kner, 1860), Silurus pintado (Natterer, 1836), S. dourado, Silurus sp., Salmo sp., and Clupea sp.; mammal Pteronura braziliensis (Gmelin, 1788); and reptiles; Caiman sclerops (Duméril \& Bibron, 1836), C. crocodilus (Linnaeus, 1758), Melanosuchus niger (Spix, 1825), Tupinambis teguixin (Linnaeus, 1758), Farancia abacura (Holbrook, 1836), Eunectes murinus (Linnaeus, 1758), Boa constrictor (Linnaeus, 1758), Crotalus horridus (Linnaeus, 1758), Ophis merremi (Wagler, 1824), Spilotes pullatus (Laurenti, 1768), Bothropoides jararaca (Wied, 1824), Dimades plicatilis (Linnaeus, 1758), Micrurus sp., Tropidonotus sp., and Coluber sp. (Almeida \& Christoffersen, 2002; Sambon, 1922; Rego, 1984). In the crocodilian C. yacare, the cycle of $S$. oxycephala was observed for the first time, where larvae of $S$. oxycephala were found in the stomach and intestine and adult parasites in the lung. Sebekia oxycephala utilizes fish as an intermediate host and completes its cycle in C. yacare when it eats infected fish. Cayman yacare is distributed geographically in the central part of South America, where it is found in the north of Argentina, southern Bolivia, Brazilian Pantanal and rivers of Paraguay. It feeds on aquatic invertebrates such as mollusks and crustaceans and vertebrates (fish and snakes) (Reptile Database, 2010).

The parasite $R$. furcocerca is a typical parasite of snakes, with a Neotropical distribution. Besides Crotalus durissus (Linnaeus, 1758), this pentastomid species was recorded in various species of snakes: Boa constrictor, Coluber lichtensteinii (Raddi, 1820), Drymarcon corais (Boie, 1827), Xenodon merremii (Wagler, 1824) and Lachesis sp. (Motta, 1963; Rego, 1983). Thamnodynastes chaquensis which represents a new host for $R$. furcocerca, occurs in the provinces of the Chaco, where there are reports of this species in Argentina, Paraguay, Uruguay and Brazilian Pantanal. T. chaquensis is a nocturnal snake which is abundant in the Brazilian Pantanal, where it feeds mainly on amphibians and small rodents (Franco \& Ferreira, 2002).

Raillietiella sp. 1 found in the lung of B. mattogrossensis differs from $R$. furcocerca because the male of this species is larger than the female, but its identification at the species level was not possible due to the lack of a male in the host analysed. B. mattogrossensis occurs in Brazil (Amazonas, Goias, Mato Grosso do Sul, Rondônia, São Paulo and Tocantins), Bolivia, Paraguay and Argentina. The diet of this snake consists of anuran amphibians, small mammals, lizards, snakes and centipedes (Monteiro et al., 2006).

The parasitism of $R$. freitasi in the lizard Trachylepis atlantica (= Mabuya punctata) (Schmidt 1945) has already been reported, and besides this lizard, $R$. freitasi also parasitizes the species Tropidurus torquatus (Wield, 1820) and Rhinella schneideri (= Bufo paracnemis) (Werner, 1894) (see Almeida \& Christoffersen, 2002). Trachylepis atlantica is a lizard endemic to the Fernando de Noronha Archipelago; this species of omnivorous lizard, feeds mainly on plant material and insects, typically ants (Rocha et al., 2009).

The specimen Raillietiella sp.2 found in Liophis poecilogyrus (Wied-Neuwied, 1825) constituted the first report of infection by pentastomids in this species of snake. The identification of the parasite at the species level was not possible due to the lack of a male. The snake $L$. poecilogyrus is a species with wide geographic distribution, occurring from the eastern part of Guiana to southeastern Venezuela, advancing in a south-to-southeast direction down to Bolivia and Paraguay, also reaching the Pantanal and continuing down to the Argentinian Pampas and Chaco (Reptile Database, 2011); it feeds mainly on amphibians, particularly members of the families Bufonidae and Hylidae (Pinto \& Fernandes, 2004).

Although important studies on pentastomids have been published in recent years, knowledge of these parasites in Brazil still needs to be substantially extended, since the majority of the species of Squamata and vertebrates in general that are definitive hosts of these parasites still lack studies aimed at learning about the fauna of associated pentastomids and their ecological and evolutionary relations with their vertebrate hosts.

\section{References}

ALMEIDA, WO. and CHRISTOFFERSEN, ML., 1999. A cladistic approach to relationship in Pentastimida. Journal Parasitology, vol. 85 no. 4, p. 695-704. PMid:10461951. http:// dx.doi.org/10.2307/3285745

-, 2002. Pentastomida. In MORRONE, J. and LLORENTEBOUSQUETS, J. (Eds.). Biodiversidad, Taxonomía y Biogeografía de Artrópodos de México: hacia una síntesis de su conocimiento. México: Universidad Nacional Autónoma de México. 690 p.

ALMEIDA, WO., BRITO, SV., FERREIRA, FS. and CHRISTOFFERSEN, ML., 2006a. First record of Cephalobaena tetrapoda (Pentastomida: Cephalobaenidae) as a parasite on Liophis lineatus (Ophidia: Colubridae) in northeast Brazil. Brazilian Journal of Biology, v. 66, no. 2a, p. 559-564. http:// dx.doi.org/10.1590/S1519-69842006000300023

ALMEIDA, WO., FERREIRA, FS., BRITO, SV. and CHRISTOFFERSEN, ML., 2006b. Raillietiella gigliolii (Pentastomida) infecting Amphisbaena alba (Squamata, Amphisbaenidae): a first record for northeast Brazil. Brazilian Journal of Biology, v. 66 no. 3, p. 1137-1139. http://dx.doi. org/10.1590/S1519-69842006000600022

ALMEIDA, WO., FREIRE, EMX., and LOPES, SG., 2008a. A new species of Pentastomida infecting Tropidurus hispidus (Squamata: Tropiduridae) from caatinga in Northeastern Brazil. 
Brazilian Journal of Biology, vol. 68, p. 199-203. http://dx.doi. org/10.1590/S1519-69842008000100029

ALMEIDA, WO., RIBEIRO, SC., SANTANA, GG., VIEIRA, WLS., ANJOS, LA. and SALES, DL., 2009a. Lung infection rates in two sympatric Tropiduridae lizard species by pentastomids and nematodes in northeastern Brazil. Brazilian Journal of Biology, vol. 69, p. 963-967. http://dx.doi.org/10.1590/S151969842009000400027

ALMEIDA, WO., SALES, DL., SANTANA, GG., VIEIRA, WLS., RIBEIRO, SC., ALVES, RRN. and NÓBREGA, RP., 2009b. Prevalence and intensity of infection by Raillietiella gigliolii Hett, 1924 (Pentastomida) in Amphisbaena alba Linnaeus, 1758 and A. vermicularis Wagler, 1824 (Amphisbaenidae) from northeastern Brazil. Brazilian Journal of Biology, vol. 69, p. 1183-1186. http:// dx.doi.org/10.1590/S1519-69842009000500024

ALMEIDA, WO., SANTANA, GG., VIEIRA, WLS., WANDERLEY, IC., FREIRE, EMX. and VASCONCELLOS, A., 2008b. Pentastomid, Raillietiella mottae Almeida, Freire and Lopes, 2008, infecting lizards in an area of caatinga, northeast, Brazil. Brazilian Journal of Biology, vol. 68, p. 427-431. http://dx.doi.org/10.1590/S151969842008000200028

ANJOS, LA., ALMEIDA, WO., VASCONCELLOS, A., FREIRE, EMX. and ROCHA, CFD., 2007. The alien and native pentastomids fauna of an exotic lizard population from Brazilian Northeast. Parasitology Research, vol. 101, p. 627-628. PMid:17384963. http://dx.doi.org/10.1007/s00436-007-0526-7

-, 2008. Pentastomids infecting an invader lizard, Hemidactylus mabouia (Gekkonidae) in Northeastern Brazil. Brazilian Journal of Biology, vol. 68, p. 611-615. http://dx.doi.org/10.1590/S151969842008000300019

FRANCO, FL. and FERREIRA, TG., 2002. Descrição de uma nova espécie de Thamnodynastes Wagler, 1830 (Serpentes, Colubridae) do Nordeste brasileiro, com comentários sobre o gênero. Phyllomedusa, vol. 1, no. 2, p. 57-74.

LOPES, SG. and ALMEIDA, WO., 2006. Ameaças à biodiversidade de répteis na Biorregião do Araripe, Ceará. A Província, no. 23, p. $92-99$.
MONTEIRO, C., MONTGOMERY, CE., SPINA, F., SAWAYA, RJ. and MARTINS, M., 2006. Feeding, reproduction and morphology of Bothrops mattogrossensis (Serpentes, Viperidae, Crotalinae) in the Brazilian Pantanal. Journal of Herpetology, vol. 40, no. 3, p. 408-413. http://dx.doi.org/10.1670/0022-1511(2006)40[408:FR AMOB]2.0.CO;2

MOTTA, CS., 1963a. Considerações sobre o gênero Raillietiella Sambon, 1910. Atas da sociedade de Biologia do Rio de Janeiro, no. 2 , p. 8-10.

-, 1963b. Considerações sobre o gênero Cephalobaena Heymons, 1922 (Linguatulida). Cephalobaena tetrapoda Heymons, 1922. Atas da Sociedade de Biologia do Rio de Janeiro, no. 4, p. 7-11.

PINTO, RR. and FERNANDES, R., 2004. Reproductive Biology and diet of Liophis poecilogyrus poecilogyrus (Serpentes, Colubridae) from Southeastern Brazil. Phyllomedusa, vol. 3, no. 1, p. 9-14.

REGO, AA., 1981. Notas sobre alguns pentastomídeos de répteis. Memórias do Instituto Oswaldo Cruz, vol. 44, p. 233-238.

-, 1983. Pentastomídeos de répteis do Brasil: revisão dos Cephalobaenidae. Memorias do instituto Oswaldo Cruz, vol. 78, no. 4, p. 399-411.

,- 1984. Sinopse dos pentastomídeos da região neotropical. Garcia de Orta, Série Zoologia, vol. 11, p. 45-56.

Reptile Database, 2010. Available from: <http//jcvi.org/reptiles/ species>. Access in: 08 mar. 2010.

-, 2011. Available from: <http//jcvi.org/reptiles/species $>$. Access in: 16 jun. 2011.

ROCHA, CFD., VRCIBRADIC, D., MENEZES, VA. and ARIANI, CV., 2009. Ecology and natural history of the easternmost native lizard species in South America Trachylepis atlantica (Scincidae), from the Fernando de Noronha Archipelago, Brazil. Journal of Herpetology, vol. 43, no. 3, p. 450-459. http://dx.doi. org/10.1670/07-267R2.1 